\title{
Los intersticios \\ entre las rutinas \\ de los textos
}

Patricia Alzate J aramillo (palzate@univalle.edu.co) Profesora Asistente. Miembro del Grupo de Investigación en Periodismo e Información.

Escuela de Comunicación Social, Facultad de Artes Integradas, Universidad del Valle.

RESUMEN

Este texto, uno de los capítulos de la investigación Rutinas periodísticas y ampliación de agendas sociales en Cali, presenta un análisis de caso de algunos medios de comunicación locales y centrales en torno a las rutinas informativas y la ampliación de las agendas mediáticas. El texto pretende demostrar que las alianzas entre políticas de mercado y políticas editoriales se han simbiotizado a tal grado que, contrario a lo que habría sucedido hace una década por lo menos, ambas se integran de manera naturalizada en el periodista de medios masivos comerciales.

PALABRAS CLAVE

rutinas de producción informativa, periodismo en Cali, periodismo y mercado.

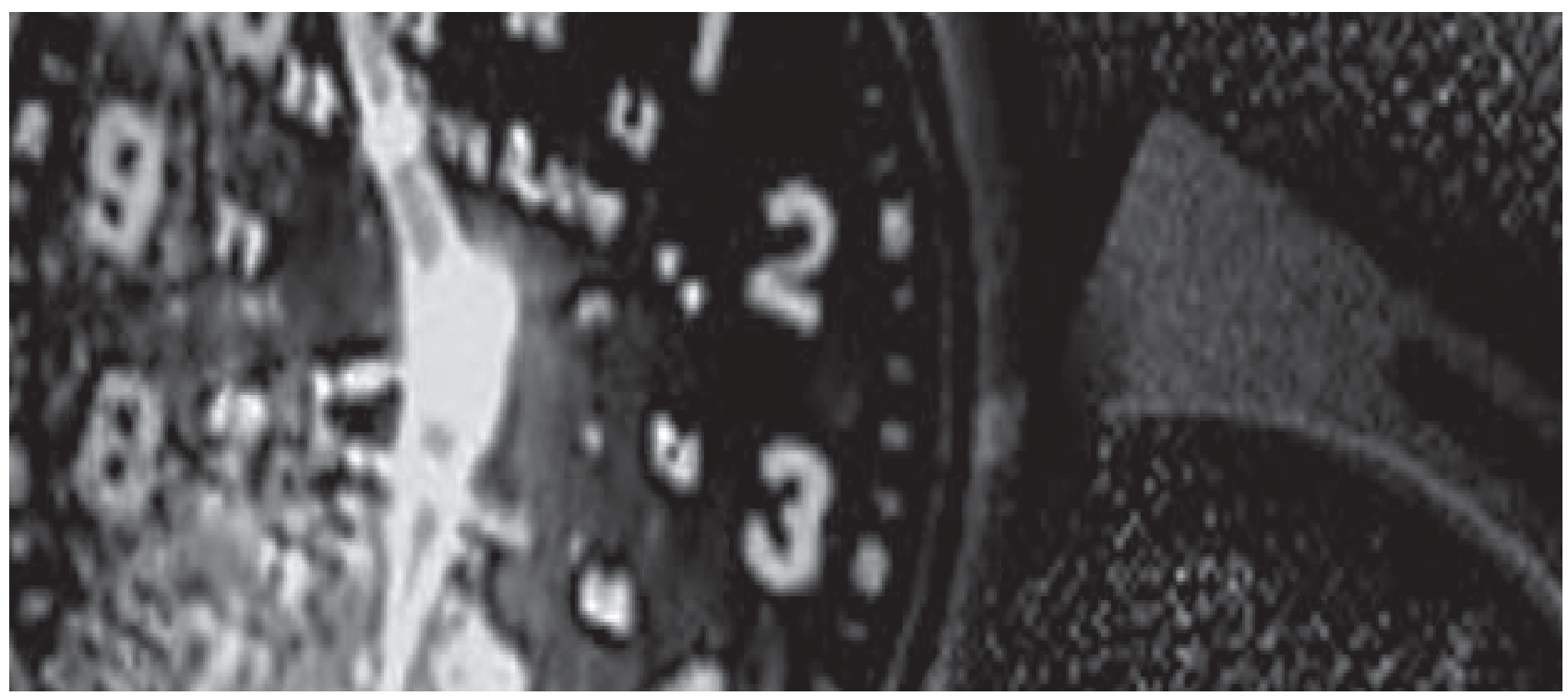




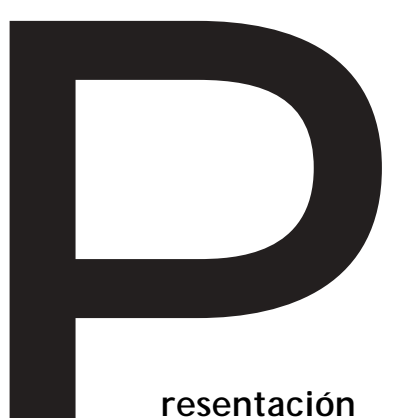

El periodismo se debate cada vez con más fuerza en el dilema de asumir las incertidumbres contemporáneas comunes a muchas otras profesiones. En su caso en particular, esta especie de zozobra puede comprenderse desde una serie de variables que se mueven en dos extremos. Por una parte, la «proletarización» de un periodista promedio, de bajo perfil, del común - es decir, la mayoría- con una subordinación conceptual e ideológica a las lógicas mediáticas en las que trabaja, con unas condiciones salariares en su mayoría precarias, con una vida personal y familiar acorralada por las extensas jornadas de trabajo y con unos ritmos de producción tan mecanizados como los de cualquier otro tipo de fabrica. Por otra parte, la consagración de un sector de periodistas que terminan convertidos en especies de «intelectuales orgánicos», orientadores e intérpretes de la vida social que representan en los medios para los cuales trabajan, o que son Ilamados con cierta frecuencia a cumplir el rol de especialistas. $Y$ entre ambos extremos se agita lo que Pierre Bourdieu denomina «la estructura invisible» (1996:57), que condiciona las relaciones de cada medio con sectores políticos, gubernamentales, educativos y económicos, $y$, en consecuencia, las representaciones de la realidad social que pasa a través de ellos.

Podría decirse que en medio de su propia inestabilidad (laboral, económica, familiar), el periodista debe encargarse de representar el igualmente inestable y convulsionado universo social desde una perspectiva que propenda a la estabilidad, al llamado al orden, a la promoción de una sociedad adecuada a unos principios generales - institucionales, legales- que la gobiernan. Un llamado al orden que se presenta en un sociedad global en la que las diferencias se hacen cada vez más visibles y en la que es indudable el crecimiento de problemáticas y de sectores sociales que confrontan los modelos institucionalizados y estereotipados de representación de la realidad.

Este trabajo de investigación se propone ingresar a esos intersticios que se esconden entre la rutina de las ruedas de prensa, del teléfono y de los boletines que llegan a las salas de redacción - modos como por excelencia se obtiene información- y el contacto directo que los periodistas tienen con esa sociedad diversa y problemática mencionada anteriormente, y a la cual ellos también pertenecen. En ese sentido, analiza el modo como algunos medios de comunicación masivos locales incorporan en sus agendas informativas temáticas y fuentes de información que escapan de los criterios de noticiabilidad coherentes con un modo burocratizado y oficinesco de hacer periodismo ligado fundamentalmente a las fuentes oficiales; y que para hacerlo, salen de sus nichos de trabajo y se desplazan para entrar en contacto cara a cara con una comunidad. Esto, que sentados en un salón de clases nos parece tan obvio y a la vez tan imprescindible para hacer periodismo - salir, observar, conversar, escuchar, estar...- no es ni lo uno ni lo otro en un medio de comunicación masivo de carácter diario. 
El trabajo empírico de esta investigación se centró en las experiencias de Cómo amaneció Cali, Noticiero del Pacífico (ya desaparecido) y Diario Occidente. Además se han tenido como referencia otras experiencias mediáticas que dan cuenta de esa inclusión de otros temas y fuentes de información, particularmente la sección «Correcaminos en los barrios» de Noticias RCN.

\section{Metodología}

El objetivo general de esta investigación fue establecer un diálogo entre las rutinas de producción y los textos escritos en un grupo de medios de información en torno a la ampliación de la agenda informativa. Pero a su vez, como objetivo secundario, se encuentra el de presentar el contexto general en el que se inscribe esta tendencia. Lo anterior supuso, en primer lugar, la selección de textos impresos (periódicos) y audiovisuales (radio y televisión) seleccionados con tres criterios: primero, textos que den cuenta en el transcurrir de una semanada rutinaria de la presencia de las fuentes de información, especialmente para ubicar las que he denominado fuentes ciudadanas ${ }^{1}$. Segundo, textos referidos a las experiencias mediáticas analizadas en las que de hecho estas fuentes ciudadanas en sus diferentes sub-clases toman un mayor protagonismo; en el primer caso, interesa tener en cuenta la frecuencia de dichas fuentes; en el segundo, el tratamiento que éstas reciben. Tercero, textos de diferentes medios y de diferentes momentos, que permiten ilustrar las tendencias que el problema de investigación presenta de modo más general y en co-relación con el corpus principal. Con este acopio diverso de textos no pretendo hacer un análisis de contenido en términos formales, sino más bien establecer asociaciones, diálogos y

yuxtaposiciones entre éstos y los problemas planteados; para ello, requiero de un cierto margen de libertad.

En segundo lugar, con el análisis de las rutinas profesionales de un grupo de periodistas interesa analizar los modos de acercamiento a esas otras fuentes no oficiales - las fuentes ciudadanas- y la manera en que las lógicas de producción del medio inciden en que se acudan a ellas o no. Es decir, a rutinas profesionales nos estamos refiriendo a un análisis de las prácticas de un grupo de periodistas de los medios seleccionados, tanto en el día a día de su trabajo en las salas de redacción, como en el cubrimiento de los eventos especiales. En términos metodológicos analizar las rutinas implica dos cosas:

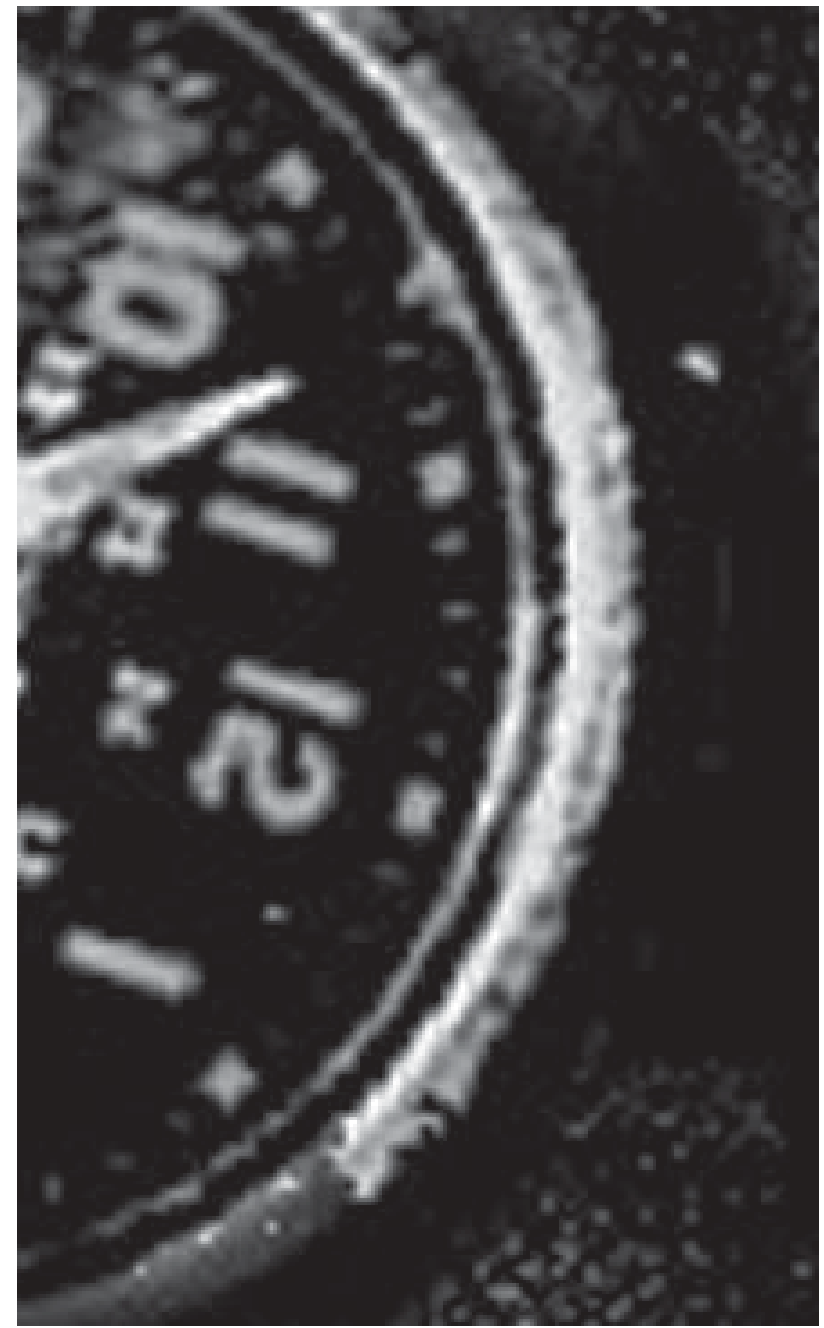

a) Seguimiento y observación del desempeño de los periodistas en sus ámbitos laborales, tanto en las salas de redacción - asistencia a consejos de redacción, presencia en la escritura de informes, en la edición de notas de televisión, en la emisión del programa radial- como fuera de ellas, específicamente en el cubrimiento de los eventos especiales: conversaciones con las fuentes, elaboración de entrevistas, organización del equipo de trabajo (Toma de las Comunas, Concejos Comunales, y eventualmente otras salidas).

b) Entrevistas a los periodistas seleccionados, todas ellas en los mismos lugares de trabajo. Los núcleos temáticos de dichas entrevistas fueron los siguientes: trayectoria personal en periodismo; trayectoria en el medio al que pertenece; relaciones con las fuentes; participación en los eventos especiales; relación con las fuentes comunitarias y oficiales; rutinas de producción; aporte de la participación en dichos eventos a su formación. 
En lo relativo al análisis de textos, si bien ha sido estricto en la selección de una semana para analizar el comportamiento de los medios, ha sido mucho más laxo en la referencia a los demás materiales, muy especialmente cuando se ha tratado de ponerlos en co- relación con las rutinas de producción. En lo relativo al seguimiento de las rutinas profesionales dentro de las salas de redacción, debe destacarse las dificultades que esto genera cuando se trata de ingresar a espacios regulados por normas de seguridad, horarios y ritmos de trabajo que restringen el acceso; en cambio, en el seguimiento a los eventos periodísticos especiales, en el caso de Occidente y Noticiero del Pacífico, al tener en mano cámara fotográfica y grabadora, la distinción entre quienes hacíamos el trabajo de campo para la investigación y los periodistas encargados de elaborar las notas no era notoria; de otra parte, fue en estos encuentros donde se facilitó la conversación informal y más desprevenida con los reporteros, con el equipo de producción y con los habitantes de los sectores visitados, en su mayoría líderes comunitarios.

\section{Rutinas y textos}

«... Si yo llego y me encuentro con la historia de un viejito que está en la miseria y que hace algo relevante, 0 un personaje cualquiera, pues propongo la nota y me dicen: 'sí, hágala'. Eso ya no es cuestión mía. Yo tengo que decirle a Adriana (su jefe):' está esto o encontré esto, ¿lo podemos hacer o no lo podemos hacer?' Ella es la que define la parte periodística como tal. Y pues también es una cosa de suerte, porque es de lo que vaya apareciendo...».

(Andrés F. Andrade, practicante de la sección «El Correcaminos», de Noticias RCN).

Cuando un periodista se pregunta qué tipo de información buscar, qué tipo de fuentes consultar y cómo elaborar la nota final no acude solamente a su valoración personal sobre el tema sino también a los criterios de noticiabilidad del medio de comunicación al que pertenece. Si se acepta el tema - si el jefe inmediato lo acepta-, esta aprobación supone un tratamiento coherente con las políticas editoriales del medio. Y todo lo anterior debe ajustarse -y explicarse- por las lógicas de producción: hora acordada para tener lista la nota, espacio o tiempo con el que se cuenta, tareas paralelas por realizar, etc. Cada una de las partes del proceso tiene que coincidir con el todo.
Aquí se ha logrado trabajar conjuntamente con el camarógrafo, con el asistente, hasta con los conductores si se da el caso... (Idem)

Patrick Charaudeau denomina instancia de producción mediática a esa entidad compleja que integra distintos tipos de actores en un medio de comunicación: los dueños de las empresas, los gerentes, los directores, los redactores, los fotógrafos y los técnicos. De modo que aunque se trata de un trabajo construido a diversas manos, todos los que intervienen de una u otra manera en la producción de ese discurso contribuyen a elaborar una enunciación «aparentemente unitaria y homogénea» (2003:96). En ese sentido, se constituye más bien en una co- enunciación cuya «intencionalidad significante corresponde a un proyecto común a esos actores y que representa la ideología del órgano de información. De ahí viene su convencionalidad»². Convencionalidad que, además, no se limita a un medio de comunicación en particular sino al sistema de medios en general, lo que se advierte en la utilización de procedimientos similares en la selección y escritura de los temas (noticias que ocupan las primeras páginas, tipos de titulares, fuentes consultadas, etc.). A lo anterior tendríamos que sumar lo que Pierre Bourdieu denomina el «efecto de inter- lectura», según el cual las primeras fuentes de información para los periodistas son su competencia: «para saber 10 que uno va a decir hay que saber lo que han dicho los demás» (1996:31). En lo relativo a la ideología del órgano de información que menciona Charaudeau, debemos recordar que ésta se encuentra supeditada a sus condiciones de propiedad y, en consecuencia, a sus alianzas políticas y económicas; pero también a sus relaciones con los demás actores de la sociedad. Aún corriendo el riesgo de caer en una especie de determinismo, lo que quiero mostrar es que en las decisiones aparentemente más nimias e individuales en el proceso de construcción de información intervienen también factores internos y externos no tan insignificantes.

- No sé por qué se les ha metido a ustedes que llegar primero es informar mejor...

- Me extraña que no sepas eso, José Vicente, no sé cómo has llegado a ser director de un noticiero.

- Para que vea, y el primero en sintonía. (Debate televisivo entre los periodistas J osé Vicente Arizmendi y Raúl Ramírez. Programa Versión Libre, Telepacífico, 19993) 
La noción de campo periodístico puede ser útil para ubicar el entramado de decisiones particulares y estructurales que intervienen en el periodismo. Pierre Bourdieu lo define como «... un espacio social estructurado, un campo de fuerzas - hay dominantes y dominados, hay relaciones constantes, permanentes, de desigualdad que se desarrollan dentro de este espacio- que es también un campo de luchas para transformar o conservar ese campo de fuerzas» (1996: 59). Para el caso específico del periodismo, estamos hablando de un campo con unas reglas de juego internas que - de acuerdo a la posición que se ocupe- establecen relaciones de fuerza entre los distintos agentes participantes. La misma estructura organizativa de un medio da cuenta de ello - los roles de dirección, de jefatura de redacción, de directores de secciones, de reporteros rasos, de corresponsales, etc. -. Pero también el prestigio que le corresponde a cada periodista en el contexto de su propio medio. Y el lugar de ese medio en el contexto mediático más general.

Veamos el caso del periodista citado al inicio del texto, quien plantea el desprevenido ejemplo de seleccionar para una nota a un viejito en la miseria que, además, hace algo relevante. Esta decisión, que debe ser consultada a su jefe y aprobada por ella (la coordinadora de la sección El Correcaminos, de $\mathrm{RCN}$ ), está inscrita en una sección del noticiero cuyo propósito es tener un acercamiento con los habitantes de los barrios bogotanos para que denuncien las situaciones que no funcionan en sus sectores (ciudadanos víctimas y ciudadanos organizados) y para que presenten sus facetas positivas, algunas de ellas muy al estilo del periodismo de soluciones (actores modelo, hijo pródigo). Desde esa perspectiva, la historia de un viejito en la miseria (víctima) se torna pertinente periodísticamente porque realiza una actividad destacada en su comunidad - no sabemos cuál- (actor modelo). Pero además responde al menos a dos demandas que aparentemente coinciden sin traumatismos:

1. «... La gente de mercadeo y de rating nos dio unas pautas; entonces nosotros con base en esas pautas que ellos nos dan vamos recorriendo, vamos cambiando, de norte a sur, de occidente a oriente, tratando de descentralizarnos» (Adriana Ayala).

En primer lugar, los bajos niveles de recepción del noticiero en su sede de origen, Bogotá. De modo que las demandas de los receptores y las preocupaciones de la sección de Mercadeo - basadas en estudios técnicos- son las que permiten construir el producto periodístico en cuestión. Al lado de El Correcaminos, este noticiero tiene otras secciones que buscan establecer un contacto más directo con los receptores (Usted Elige, El Cazanoticias, el chat; además de secciones de salud y cocina). Debe tenerse en cuenta, además, que la irrupción de canales locales masivos, como City TV, empiezan a constituirse en una importante competencia para captar los públicos locales; de hecho emiten un noticiero a la misma hora.

2- «Nos empezamos a dar cuenta que había un vacío entre el canal y la gente... Comenzamos a notar que a la gente le interesaban ciertas cosas que uno normalmente no hacía que era ir al barrio y hablar con ellos (...) mostrarle al otro país qué es Bogotá de una forma distinta, que no es solamente la noticia titular, sino que hay barrios, hay gente, hay personajes» (Idem).

En segundo lugar, las demandas espontáneas y recurrentes de los habitantes de la ciudad para que se den a conocer los defectos y virtudes de los barrios que habitan. En ese sentido, es importante tener en cuenta la presión que ejercen ciertos sectores sociales para ingresar a la agenda de los medios y el carácter poroso de éstos para acogerlos y adaptarlos a sus estándares.

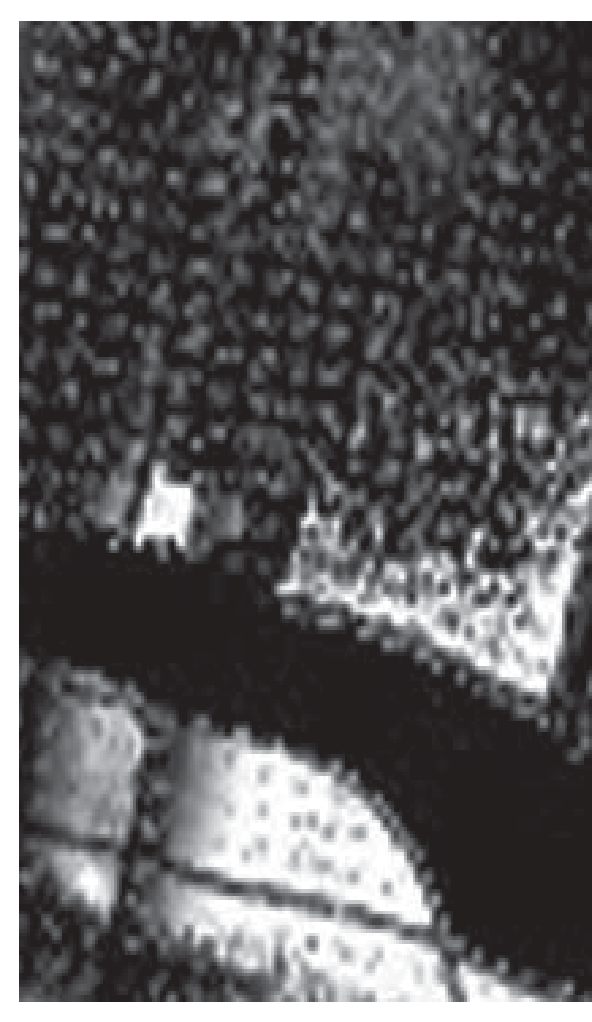




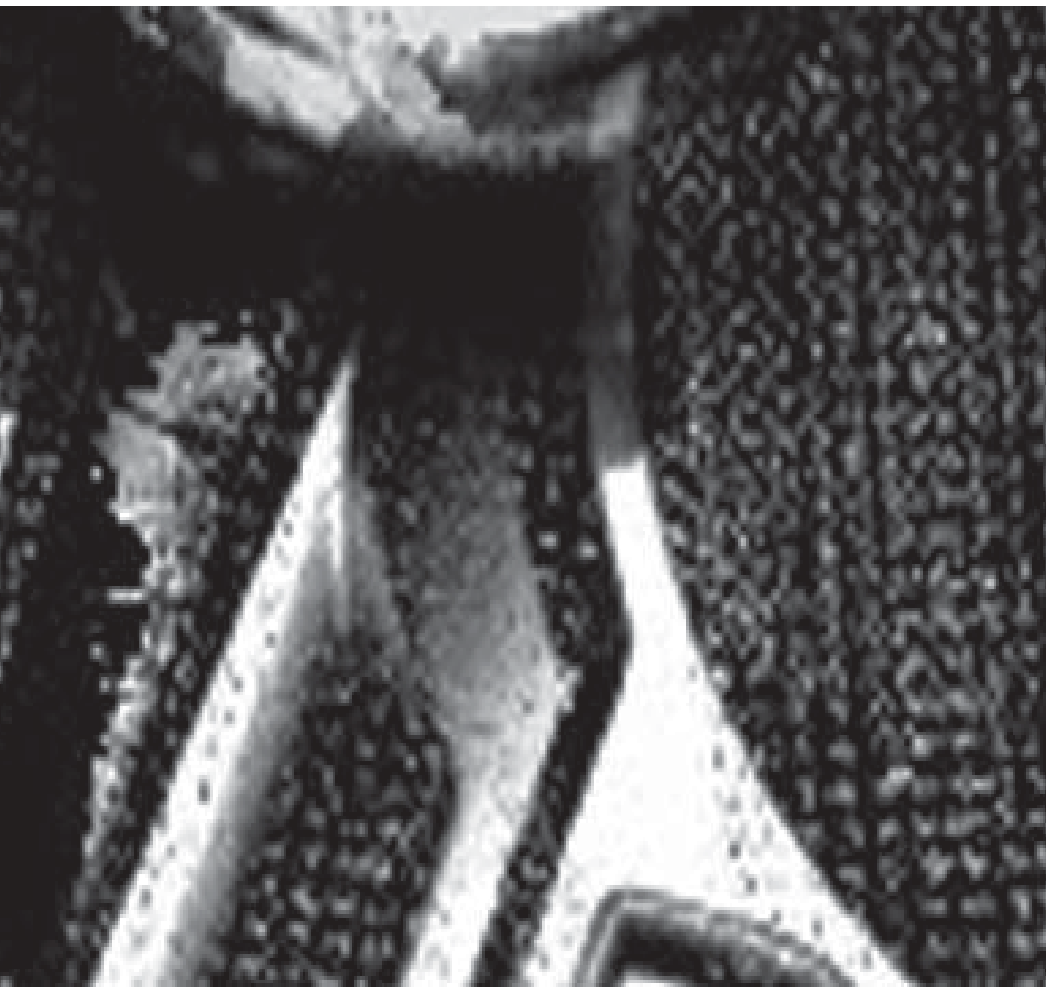

- ¿Y esas pautas que les dan para mejorar el rating afectan lo que ustedes hacen periodísticamente en cada sector?

No afectan, porque precisamente nosotros nos basamos en eso para llegar a aquellos sitios donde seguramente no nos ven, donde RCN no tiene la acogida que quisiéramos que tuviera. Entonces, esa es la idea, llegar a esos sitios para mostrar más presencia por parte de RCN; para decirles: bueno, señores aquí estamos, cuéntenos su propia historia, cuéntenos sus problemas, cuéntenos también sus cosas positiva (Adriana Ayala).

Aunque es evidente el peso del factor económico en la decisión de crear la sección, no deben menospreciarse las razones de orden periodístico: denunciar y destacar. Ni tampoco la naturalidad con que la periodista entrevistada relaciona una cosa con otra. Pierre Bourdieu nos dice: «Hay una serie de relaciones de fuerza invisibles cuya comprensión requiere conocimiento de las fuerzas objetivas que constituyen el campo (...) Para comprender las decisiones de un periodista deben tenerse en cuenta las relaciones del medio con el que trabaja en el campo del periodismo y en su medio el lugar que ocupa» (1997). En este caso la influencia del campo económico en las decisiones editoriales y el interés de recuperar unos públicos cooptados por la competencia son asimilados de manera obediente por una periodista- empleada que tiene una relación de subordinación con los directores del medio, y que a su vez, inscrita en la ideología de éste, tiene una cierta independencia en la coordinación de la sección: la estructura jerárquica en un medio de comunicación no es muy flexible, pero una vez se tenga claro el rol que cada uno cumple, hay una cierta movilidad para hacer el trabajo. La interiorización de la norma permite el funcionamiento del medio... y del sistema de medios.

«La filosofía en términos generales y nacionales de la información es la misma, siempre temas que le interesen a la comunidad y que tengan dos ítems fundamentales que representan la noticia y que son de inmediatez y de cercanía, es decir, cosas que nos toquen directamente que tengan una proyección nacional y que sean inmediatos; pero cuando entramos al ámbito local cambia sustancialmente y es que la información local tiene que ser eso, es-tric-ta-men-te local y de interés comunitario pero en Cali».

(Guillermo Vallejo, director de noticias Caracol Cali)

A esa interiorización de la norma la denominaremos ideologías profesionales: «una teoría implícita generada, mayoritariamente compartida y reproducida por los miembros de determinada profesión» (Abril, 1997:307). Teoría implícita que, además, tendría como función distintiva la de otorgar prestigio a los miembros del gremio correspondiente y que estaría sostenida y reproducida fundamentalmente, de manera vertical, por las élites profesionales: De las élites a los sectores subalternos, y de los miembros veteranos a los sectores novatos» ${ }^{4}$. De ese modo, estaríamos hablando, en primera instancia, de un sector relativamente cerrado que tendría la legitimación necesaria para definir las reglas que rigen a una determinada profesión y, en segunda instancia, de otro sector que asume dichas reglas y las pone en práctica en su ejercicio profesional ${ }^{5}$. Instalada en la estructura invisible del medio, la periodista de El

Correcaminos cumple con las tareas que le corresponden y en su testimonio no se advierte desazón ni cuestionamiento sobre su tarea. Por el contrario, expresa una identidad institucional por la empresa en la que trabaja y una adhesión por los valores sociales que ésta adopta: la denuncia y la cara positiva como criterio de noticiabilidad para representar a una comunidad. Lo mismo puede decirse del periodista de Caracol, quien explica con convencimiento los criterios de 
noticiabilidad de su medio: inmediatez y cercanía con servicio a la comunidad. En ninguno de estos dos casos, ni en muchos otros, hay atisbos de inconformidad con lo que hacen ni de que quisieran hacer otra cosa (a lo sumo hacer otra cosa se refiere a hacer una nota más extensa). En ese sentido las ideologías profesionales se constituyen en una forma de control social en el interior del medio que funcionan de manera inconsciente y que se transmiten progresivamente. Traigo a colación una extensa cita del sociólogo francés Alain Accardo, dedicado a estudiar lo que ha denominado «socioanálisis del periodismo»: «El analista del sistema mediático debería plantearse en principio que los periodistas, en amplios sectores, en su inmensa mayoría, no están maquiavélicamente preocupados por manipular al público para el mayor beneficio de los accionistas de las empresas en particular y de los inversores capitalistas en general. Aunque se comporten como 'condicionadores' de aquellos a los que dirigen, no es tanto porque tengan la voluntad expresa de condicionarles, sino porque ellos mismos están condicionados hasta un nivel que la mayoría ni sospecha. Al hacer cada uno espontáneamente lo que tiene que hacer - 0 no haciéndolo- se pone de acuerdo espontáneamente con todos los demás. Se podría decir, como el poeta Robert Desnos, que responde a la lógica del pelícano: 'El pelícano pone un huevo blanco. Del que sale, inevitablemente, otro que hace lo mismo'» (2000).

- Raúl, ¿usted por qué se fue detrás de los secuestrados?

- Por que soy buen periodista.

(Programa Versión Libre, Telepacífico, 1999)

«Lo ético para mí es la verdad, la noticia, y por verificar una información puedo llamar en plena madrugada a un general. Me pueden tildar de imprudente, pero no de incapaz»

(Álvaro Miguel Mina) ${ }^{6}$

La interiorización de las ideologías profesionales se traduce en algunos casos en discursos que refuerzan muletillas y lugares comunes, y en prácticas irreflexivas e inerciales que bien pueden inspirarse en algunos casos en la maquiavélica idea de que el fin justifica los medios. Cuando Riszard Kapuscincki dice que el cinismo es una actitud incompatible con la profesión de periodista, se está refiriendo a lo que él Ilama «gran periodismo, que es el único del que vale la pena ocuparse, y no de esa forma detestable de interpretarlo que con frecuencia encontramos» (2002:53). Según lo anterior, en esa forma detestable de hacer periodismo a la que pertenecerían los que él mismo llama los siervos de la gleba, vinculados evidentemente con medios masivos, sí cabría el cinismo. Sin embargo, eso que visto desde afuera supone un pragmatismo tal que deshumaniza al periodista, no necesariamente es visto del mismo modo dentro de su entorno. A pesar del talante utilitarista como el joven periodista se refiere a las bondades de encontrar un «viejito en la miseria» para hacer una nota, obra de «buena intención» en tanto aplica voluntariamente los criterios que en su medio le exigen; del mismo modo el periodista que arriesga la vida tras una persecución entre militares, secuestrados y secuestradores, lo hace con la convicción de que ésa es la mejor manera de conseguir información; aunque de hecho esté la amenaza de perder su trabajo si no consigue una buena chiva, lo que prima es el interés de hacer bien su trabajo, ser buen periodista. Nos dice Accardo. «Los financieros y los empresarios que controlan (en lo esencial y por distintas razones) los medios de comunicación no tienen generalmente necesidad de dictar a los periodistas lo que deben decir o mostrar. No tienen necesidad de violentar su conciencia ni convertirles en propagandistas (...). Hay un reproche que no puede hacerse a los periodistas, salvo en casos particulares: el de no hacer su trabajo de buena 
fe. Habiendo interiorizado ampliamente la lógica del sistema, se adhieren libremente a los que se les induce a creer. Actúan de común acuerdo sin necesidad de ponerse de acuerdo.» (2000). Es claro que esto no funciona como ley general, pero la estructura de un medio de comunicación tiene una enorme capacidad de lograr la adhesión de sus trabajadores?

De modo pues que esas ideologías profesionales «gobiernan los aspectos pragmáticos (empíricos antes que teóricos) del ejercicio profesional» (Ramírez, 1997) y, en esa medida, guardan una estrecha vinculación con las rutinas de producción, entendidas como «un procedimiento operativo tipificado» que tiene lugar en organizaciones complejas cobijadas por unos sistemas de reglas y procedimientos estandarizados (Abril, 321). Es en ese escenario donde son reproducidas por unos subordinados - los periodistas- esa serie de valoraciones en torno a la profesión y donde se toman las decisiones operativas.

\section{La rutina del texto}

La finalización de la rutina diaria culmina una vez el mensaje periodístico está listo. La hora de cierre en un periódico, o el inicio de la emisión en medios audiovisuales, da comienzo al ensamblaje de las piezas que configuran el producto final. El mensaje, el texto, la nota, el directo... son el punto de Ilegada de un extenuante proceso previo. Patrick Charaudeau, propone una noción de discurso no restringida «a las reglas de uso de la lengua», sino una en la que sea fundamental tener en cuenta los contextos en los que éste se genera y se recibe - instancias de producción y de recepción, respectivamente -: «El discurso es lo que enlaza las circunstancias en las que se habla o escribe con lo que se dice. Las circunstancias no son sólo el lugar o el momento en el que se habla; también incluyen la identidad de quien habla y de su interlocutor, la relación de intencionalidad que los vincula y las condiciones físicas del intercambio» (2003: 49).

Teu A. Van Dijk establece, por su parte, dos dimensiones principales del análisis del discurso, la textual y la contextual, en la que la primera da cuenta de «las estructuras del discurso en diferentes niveles de descripción» y la segunda «con diferentes propiedades del contexto, como los procesos cognitivos y las representaciones o factores socioculturales». En esta última dimensión, la que más interesa para este estudio, propone un análisis integrado del texto y el contexto en tanto el uso de un discurso en una situación social constituye un acto social: «Una explicación completa del discurso periodístico, pues, exige tanto una descripción de las estructuras textuales de la noticia, como una descripción de los procesos de producción y de recepción del discurso periodístico en situaciones comunicativas y contextos socioculturales» (1996: 53).

Ahora bien, para el caso que nos ocupa no interesa detenerse en los procesos de recepción sino, fundamentalmente, en el de producción de los mensajes, teniendo en cuenta, justamente, lo que Charaudeau denomina condiciones extradiscursivas y realizaciones intradiscursivas: nos estaríamos refiriendo, en primer término, a las relaciones e intercambios que establecen los medios con las instancias que producen o promueven determinados temas $y$, en segundo término, a los condicionamientos internos tanto de los periodistas como de las organizaciones informativas que moldean la construcción de esos discursos periodísticos.

\section{Cómo Amaneció Cali}

«A partir de este momento iniciamos su noticiero Cómo amaneció Cali, 22 años de periodismo para las gentes de Cali y el Valle del Cauca. Emprendemos esta 
primera hora, la hora de servicios a los oyentes; con toda la atención a sus quejas, inquietudes, y la tradicional alegría para iniciar el día de la mejor manera posible; al estilo de Cómo amaneció Cali, el noticiero que sirve. $Y$ arranquemos con los titulares de esta primera hora de servicio».

El noticiero «Cómo amaneció Cali» fue creado en 1983 con la intención de «informar localmente y de crear un esquema nuevo para la ciudad» ${ }^{8}$. En la primera etapa del noticiero su equipo de trabajo estaba conformado por dos jefes de redacción (Godofredo Sánchez y Héctor Luna) un director (Samy Jalil, quien estuvo al frente durante diecinueve años), siete reporteros, un auxiliar y tres locutores. También contaban con secretaria propia y un carro exclusivo. Las cosas han cambiado. No sólo se pasó de tres emisiones diarias a una, la secretaria y el carro desaparecieron del inventario, y en tanto pertenece a la Cadena Básica Caracol, su equipo de trabajo debe proporcionar también información a sus otros productos (un noticiero local informativo y las emisiones nacionales). Actualmente el noticiero cuenta con un jefe de redacción- Leo Quintero-, un director - Guillermo Vallejo-, cinco periodistas y dos locutores.

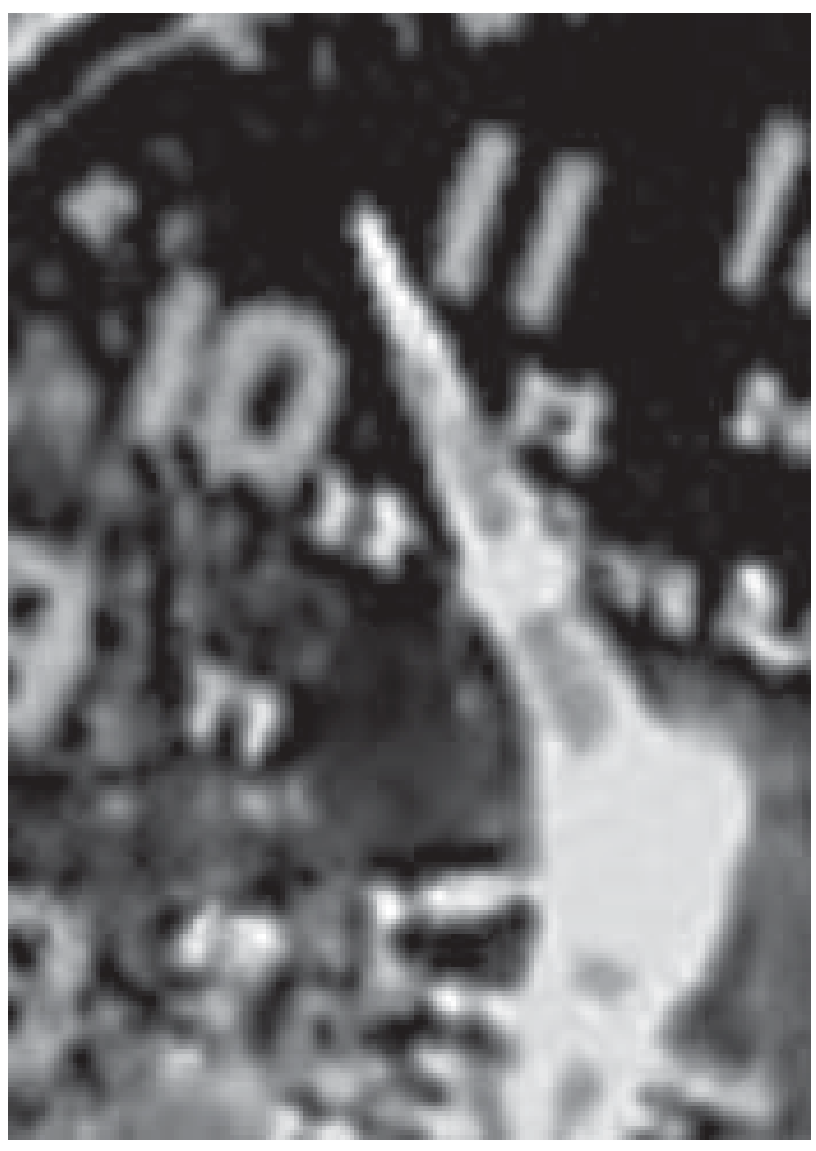

Si bien desde sus inicios este informativo radial tuvo como público las clases populares, no siempre estuvo centrado en la idea de servicio a la comunidad; en su primera temporada el criterio de noticiabilidad dominante era la crónica roja y posteriormente pasó a una etapa profusa de campañas sociales, a cargo de Sammy J alil. Estos enfoques progresivamente cambiaron: Con su slogan El noticiero que sirve a la gente, su lenguaje coloquial y el espacio al aire que concede a sus oyentes se ha concentrado en los estratos 1,2 y 3 , con la intención de que «la gente se vea reflejada en el producto informativo»9. A partir de entonces, a nivel local y con proyección nacional (se crean emisiones similares en otras ciudades), este noticiero marca un derrotero importante con respecto a la noción de la radio popular, hasta entonces muy ligada al lenguaje oral de la calle y de los temas judiciales. Si bien ambos elementos continúan a partir de una figura emblemática- el periodista Álvaro Miguel Mina- se introdujo el perfil de un conductor del noticiero mucho más serio, con credibilidad ante la audiencia, ante líderes comunitarios y ante instituciones oficiales y privadas, el periodista Leo Quintero, nominalmente su jefe de redacción pero quien cumple las funciones de director.

Ambos son periodistas empíricos de larga trayectoria en el medio radial y con prestigios en el campo periodístico de la ciudad. Mina es considerado como un excelente periodista de orden público, en tanto tiene habilidad para desplazarse, obtener información, estar en el momento y en el lugar correctos y crear emoción en sus transmisiones. Es un periodista que destaca como uno de sus modelos a seguir a Henry Holguín:

«Una vez Henry Holguín me dijo:' mirá lo que tenés debajo de los zapatos, mirá huevón'. Entonces le dije:' pues la suela'. Y me dijo: 'no, marica, el criterio; lo estás pisando'. Y eso se me quedó bien grabado...».

El prestigio de Leo Quintero como periodista empírico lo ha logrado por el conocimiento que expresa sobre el funcionamiento de la ciudad, tanto en términos administrativos como en el terreno. En ese sentido, conoce con fluidez el organigrama y funcionamiento del estado, pero a su vez, conoce con detalle las diferentes direcciones de la ciudad. Sus estrategias, en síntesis, son las siguientes: 


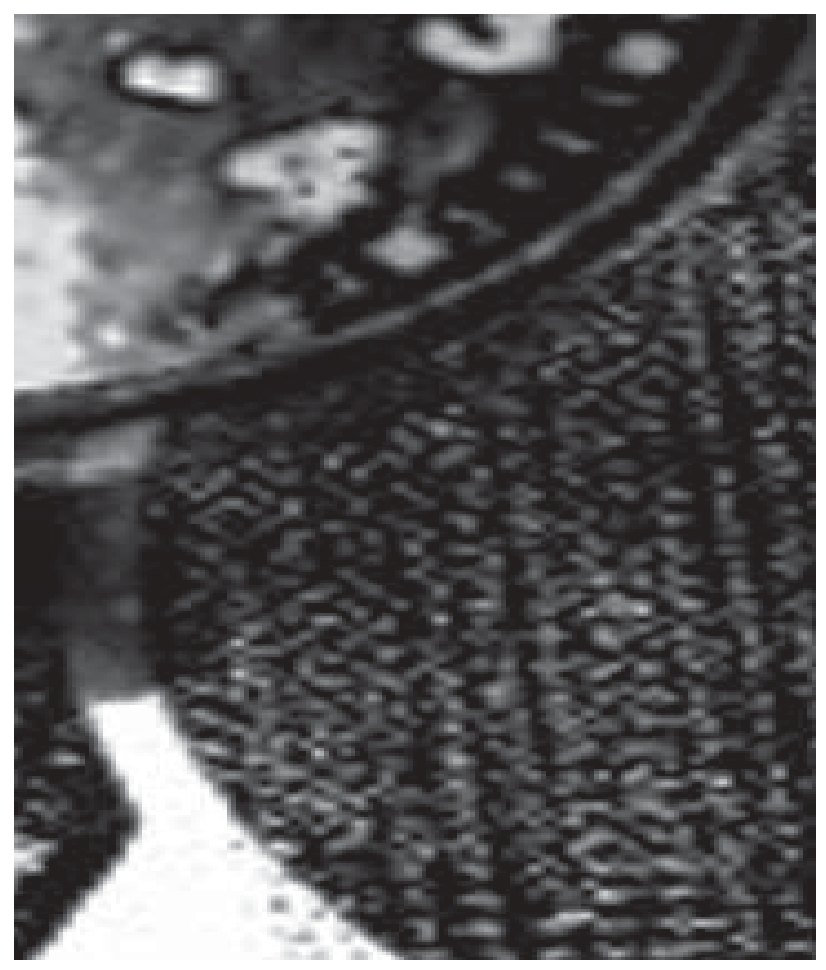

Leyendo mucho, leyendo de todo, leyendo mucho de la vida municipal, escuchando mucho a quien está hablándole a uno para tener la oportunidad de preguntarle y aprenderle (...). Cuando yo no sé de un tema llamo a alguien para que me explique, cuando escucho a una persona yo busco a alguien que me diga: 'este tipo va para tal o tal parte'. Uno no puede salir a burrear solito, tiene que tener algo en la cabeza, no puede dar opinión sin tener un bagaje de las cosas

(...)

Cuando uno habla de la ciudad de Cali hay que ir a recorrer la ciudad, y tengo un carrito en el cual le doy vueltas el fin de semana, para verla concretamente. Si alguien dice: 'estamos en tal parte' uno tiene que saber dónde queda esa parte, si yo voy a manejar un noticiero, a hacer un servicio informativo tengo que saber de qué sitio me está hablando.

Cindy Llanos, en la bitácora entregada sobre la observación de las rutinas en este medio, advirtió de este modo el contraste:

«... Al ver a Leo y a Mina juntos en cabina se evidencia el contraste de sus personalidades, que seguramente también se hecha de ver (o de escuchar) al aire. El uno mirando su monitor pantalla plana, el otro enroscando un papel mientras habla; el primero serio y solemne, el segundo risueño y jocoso; Leo corrigiendo a Mina, que sigue hablando sin pensar».
Estos dos personajes, Leo Quintero y Álvaro Miguel Mina, logran un equilibrio en el tono y en el enfoque del noticiero. De modo que desde la autonomía y estilo personal de cada uno coinciden de modo coherente en la lógica del noticiero. No se excluyen, más bien se complementan. Ambos asumen su rol desde el punto de vista de las audiencias a quienes está dirigido el noticiero. Quintero desde el rol de abanderado y defensor de las causas de estos sectores para demandar a las instancias oficiales la solución sus dificultades: En esa medida puede tomar el rol de crítico y fiscalizador ante estas instituciones; pero a su vez, de orientador de las demandas de la comunidad y de censor de acciones $u$ omisiones de algunas personas 0 sectores populares: en esa medida, le explica a algún oyente, en directo, el trámite que debe hacer para realizar alguna solicitud: a qué oficina debe ir, a quién debe dirigir una carta, no olvidarse de exigir la firma de recibido de la misma, cuánto tiempo debe esperar por la respuesta, etc.; del otro lado, puede regaña a los oyentes por su falta de civismo, de aseo, de respeto al otro, etc. Todo ello (y esto lo diferencia de otros conductores de noticieros populares, como lo fue en su momento J ohn Maro Rodríguez) lo hace desde un lenguaje que entremezcla lo coloquial y lo sobrio; lo coloquial en tanto incorpora las lógicas de una emisión radial en directo para un público popular, lo sobrio en el uso del lenguaje y de su entonación que sin ser plana, no cae en excesos. En síntesis, es enérgico, pero no grita, no interrumpe al entrevistado, no utiliza expresiones vulgares ni de doble sentido.

Álvaro Miguel es otro peso del noticiero y yo lo he metido como tal, porque me parece que maneja la parte popular muy bien. Es un excelente reportero, sagaz (...) Algunas veces se excede, entonces hay que colocarle el freno y saber qué tiempos dar a cada uno y qué manejo le da a cada información. En ese proceso de manejar la información, cada periodista tiene su background y yo nunca invado esos espacios. (Leo Quintero)

Álvaro Miguel Mina, por su parte, además de reportes judiciales y de orden público, se dedica a las «notas de color» del noticiero. Es el único periodista del equipo que sale todas las mañanas en el móvil de Caracol para transmitir en directo diálogos o entrevistas con personajes anónimos, la mayoría ubicados en espacios públicos: una galería, una calle, un puesto ambulante, etc. Si 
en el momento de la emisión del noticiero está sucediendo un evento importante, por lo general es él quien se dirige al lugar y hace la transmisión en directo. En las entrevistas expresa una mayor cercanía con los entrevistados, incluso si son éstos fuentes oficiales, y apela de modo permanente a la jerga, a las frases de doble sentido y a las anécdotas. Esto suele suceder también en su manera cotidiana de expresarse y de dar entrevistas:

- ¿Cómo organizas esas salidas a la calle?

A: Pues uno tiene una, dos, tres cosas pre-armadas, pero generalmente sobre la marcha, porque yo tengo un celular y suena todo el día, y la gente me llama:

'Mina, ve tal cosa; Mina, ve, tal otra vaina; ve, negro'; o los compañeros me Ilaman: 've, negro, en tal parte'. Uno tiene unas fuentes que son muy buenas: las empleadas del servicio y las mozas de los funcionarios, porque las mujeres (esposas) no hablan, las mozas porque viven más pendientes, usted sabe que a los funcionarios los cuida más la moza que la mujer; la mujer no sabe dónde está, pero cuidado que se le pierda a la moza... entonces ellas saben... (Entrevista a Álvaro Miguel Mina)

Al lado de las principales figuras del noticiero, intervienen otros periodistas, de carácter más sobrio y secundario, con eventuales conversaciones espontáneas y coloquiales en cabina con los miembros del equipo o con los oyentes. Dos de ellos - J uan Carlos Díaz y Martha Bocanegra- son egresados de la Universidad del Valle y de la Universidad Autónoma respectivamente. El otro - Darío Gómez- es abogado. Por lo general hay un practicante. El director nominal, Guillermo Vallejo, nunca interviene en el programa, pues conduce a la misma hora el otro noticiero local, dirigido a una audiencia de estratos más altos, y de carácter netamente informativo (sin llamadas de oyentes ni servicio social). Todos ellos deben hacer notas para los distintos noticieros: los dos locales, la emisión nacional (6:00 A.M.- 9 A.M.) y las noticias de última hora; sin embargo, la nota que se produce sobre un mismo tema tiene variaciones en el lenguaje:

«Cada uno trata de aportarle a cada una de las dos emisoras el material que cada una requiere para el tipo de oyentes al cual pretendemos llegar, entendiendo que la estructura de Radio Reloj está hecha para una masa más popular de la población y la orientación de la información en la cadena tiene otra estructura, que más económica, un poco más política dirigida a un estamento diferente de la sociedad que pretende llegar a los estratos 4, 5 y 6». (Guillermo Vallejo, director)

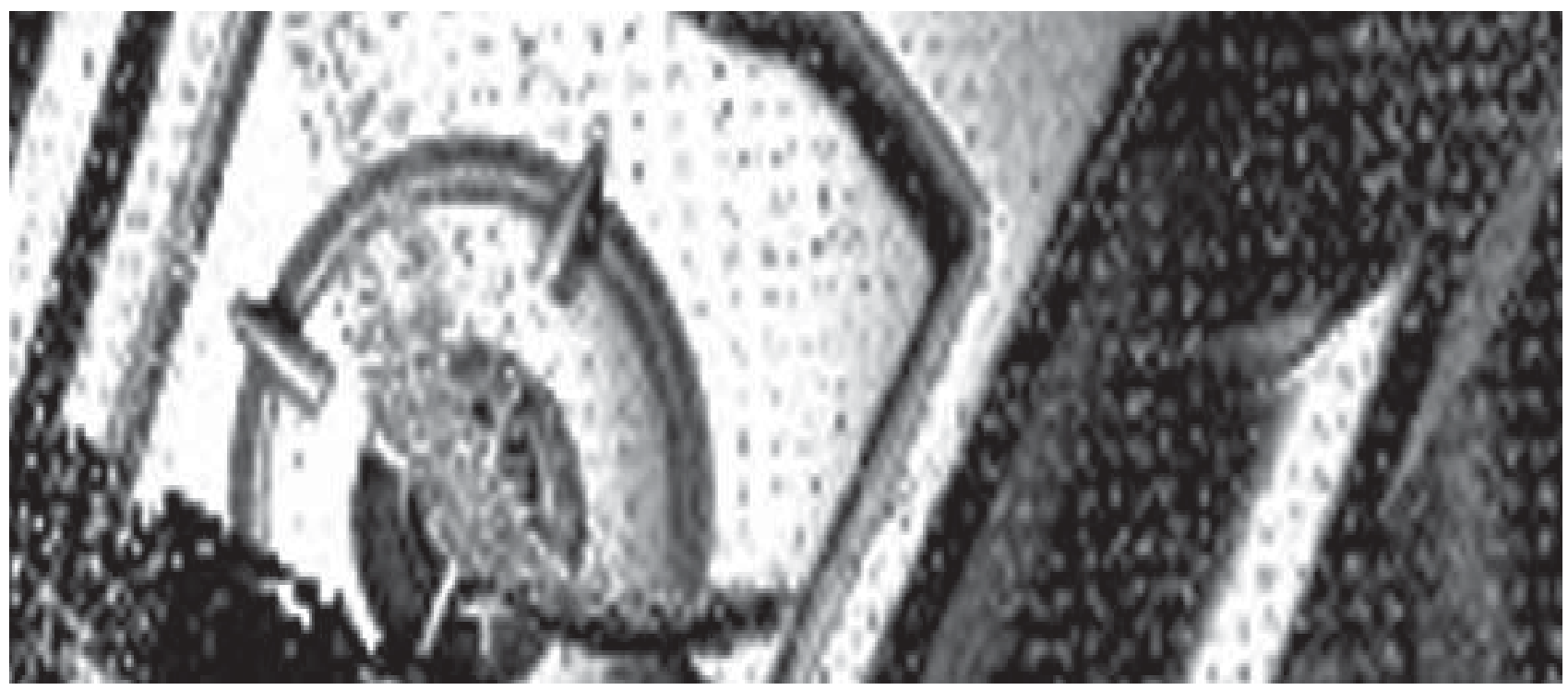


«Aquí son dos estilos. Si tu oyes a Mina en Radio Reloj y oyes a Mina en la Básica, dices:' este huevón no es el mismo'. Pero es el mismo; y la noticia es la misma, lo que pasa es que hay que darla con más adorno (...)

En la Básica digo: 'un hombre que compró una camioneta y tiene 4 embargos'. En Cómo amaneció Cali digo yo: 'un hombre que quiso cautivar a su novia, le regaló una flor y ahora tiene cuatro embargos, ¿por una flor tiene 4 embargos? No, pues una Ford Explorer de 120 millones de pesos'. Entonces, ¿si vio que es la misma noticia pero con diferente enfoque?

(Álvaro Miguel Mina)

Para la emisión rutinaria del noticiero - de 5 a 8 de la mañana- un buen porcentaje de las notas han sido grabadas desde el día anterior, aunque en algunas de ellas se apela al falso directo: el conductor le da la entrada a la nota de un periodista, quien saluda a su interlocutor y narra la noticia en tiempo presente. También se hacen entrevistas en directo, la mayoría de ellas a fuentes oficiales o a personajes importantes; y se acude a las llamadas de los oyentes. Otras informaciones son leídas directamente por los locutores del programa dos, que se expresan de manera coloquial- o por Leo Quintero. En el transcurso del noticiero Leo Quintero se comunica con personal de energía y alcantarillado de Emsirva, bomberos, tránsito de Cali y su área metropolitana, para que den reportes del funcionamiento de esos servicios:

- Tenemos comunicación con el servicio de energía para los oyentes de Radio Reloj, en Cómo Amaneció Cali. Luz Dary Gutiérrez. Luz Dary, buenos días, cómo está...

- Muy bien, gracias a dios.

- Gracias, Luz Dary, muy amable. Si es tan gentil cuénteles usted a los oyentes cómo amaneció Cali en materia de energía.

- A ver, déjeme desearle un feliz día a usted y a toda la audiencia. Te comento que en este momento la ciudad amaneció bien; gracias a dios no tenemos daños, ni mantenimientos; en este momento está todo bien.

- ¿Está todo tranquilo y calmado?

- Tranquilo y calmado; hasta ahora pues ningún daño para reparar, hasta ahorita, en este momento.

- Luz Dary, muy amable, que tenga buen día.

- Igualmente para usted y toda la audiencia.

- Muy gentil a Luz Dary Gutiérrez, del área de Empresas Públicas

Municipales de Cali. Estamos en Radio Reloj.

También se incluyen otras secciones como El Oasis Musical, resumen de noticias cada hora, frases célebres, La historia en una fecha como hoy, las condolencias, los cumpleaños, la sección política (Periscopio, de Leo Quintero), Momentos de Dios, sección presentada por el sacerdote Francisco Alvarado, y casi finalizando el noticiero, César Augusto Arias presenta la sección de deportes que, con pocas excepciones, se limita a informar sólo sobre fútbol. La primera hora del noticiero - de 5:00 a 6:00 a.m. - están dedicada por lo general a noticias de carácter judicial: entre seis y ocho de la mañana, se realizan las entrevistas en directo y las llamadas de los oyentes. A propósito de la manera familiar como se realizan las entrevistas y como dan el paso de una sección a sección, rescato este comentario de la asistente de investigación, Cindy Llanos:

Si alguien escucha el noticiero con regularidad sabrá que el saludo enérgico entre los locutores y el guía espiritual del programa es ritual, pero ¿quién les viera las caras? Sus voces expresan una alegría que sus rostros ignoran». 
Uno de esos periodistas que he denominado como secundarios, Juan Carlos Díaz, tiene un turno de trabajo de 2:00 a 10:00 p.m. y es en este lapso que debe dejar listo para quienes madrugan a las 4:00 a.m. (Leo Quintero es el primero) el esqueleto de lo que será la emisión de la mañana. A su vez, debe cumplir con los compromisos pendientes de todos los insumos de Caracol. El explica así su rutina:

Cuando yo llego aquí al turno a las dos de la tarde mis compañeros salientes me dejan una guía en mi computador de más o menos lo que está pendiente. Hay muchas informaciones que pide Bogotá que hay que sacarlas en el transcurso de la tarde, hay que leer si los compañeros la dejaron grabada o sino uno tiene que montarla. Además de eso, entre las dos y dos y media tengo que mandar un plan a Bogotá sobre los temas de los que vamos a hacer el seguimiento en la tarde hasta las diez de la noche. Luego de que mande eso mi director deja un plan de trabajo de los temas que hay que elaborar para los informativos del otro día, además de lo que uno tenga en la agenda propia. Después de las dos y media en adelante debo estar pendiente de que salga lo que más se pueda en los informativos, cada hora desde Cali dependiendo de la información que haya, y si no hay buscar una noticia que sea relevante para Colombia; (...) Tiene que haber material todos los días para sacar a nivel nacional. Entonces ya al finalizar la tarde empiezo a hacer material de mis fuentes, de las noticias que yo tengo, todos los periodistas tienen la obligación de dejar material para los tres noticieros - el de la Básica, el de las cinco de la mañana y el de las seis de la mañana-. (...) Hay tres cajones en los cuales los periodistas tenemos que dejar la información. Al finalizar la tarde voy organizando más o menos cuál es la información más importante para el otro día, voy mirando cómo está el material, tengo que hacer una relación de efemérides, cuáles son los acontecimientos que se cumplen el otro día, tengo que enriquecer el plan de trabajo del otro día. El plan de trabajo consiste en qué se va a hacer, se meten nombres y teléfonos y temas para que el periodista que esté por la mañana con Leo Quintero, que es el director del noticiero, llame y saquemos personajes al aire o temas para trabajar. Ya por ahí a las seis o siete de la noche empiezo a armar las noticias por importancia, las voy acomodando en los tres noticieros, cuál es la noticia de abrir, cuál de segunda, cuál de tercera y así sucesivamente en orden de importancia. Además de eso empezar a titularlas, todas las noticias hay que titularlas.

En esta atiborrada jornada de ocho horas, la posibilidad de hacer reportería en la calle es nula. Se trata de una rutina que requiere entonces de destrezas para cumplir a la vez variadas funciones: contando con la ayuda de herramientas tecnológicas a través de las cuales recibe información (internet y teléfono), produce textos propios y de otros, y los remodela para los tres formatos de noticieros de Caracol, de los cuales Cómo Amaneció Cali es sólo uno. Todo ello debe dar lugar a discursos periodísticos unitarios y homogéneos de acuerdo a cada medio: la instancia de producción mediática. La posibilidad entonces de caer en estereotipos, en frases clichés y en priorizar las fuentes oficiales en estas condiciones (capítulo 3) es muy alta; y se requiere, de otra parte, de una interiorización por parte del periodista de lo que, con autonomía, hay que hacer: no hay mucho tiempo para recibir órdenes y explicaciones de los jefes. $\mathrm{Si}$ el periodista duda de las tareas que tiene a su cargo, está en el lugar equivocado.

Llama la atención que a pesar del énfasis dado en el eslogan del noticiero y en las entrevistas a la presencia de las audiencias y de la comunidad en el programa, si hace una revisión detallada de lo que pasa en una semana rutinaria, se verá que la prioridad en la información (notas y entrevistas) siguen siendo las fuentes oficiales:

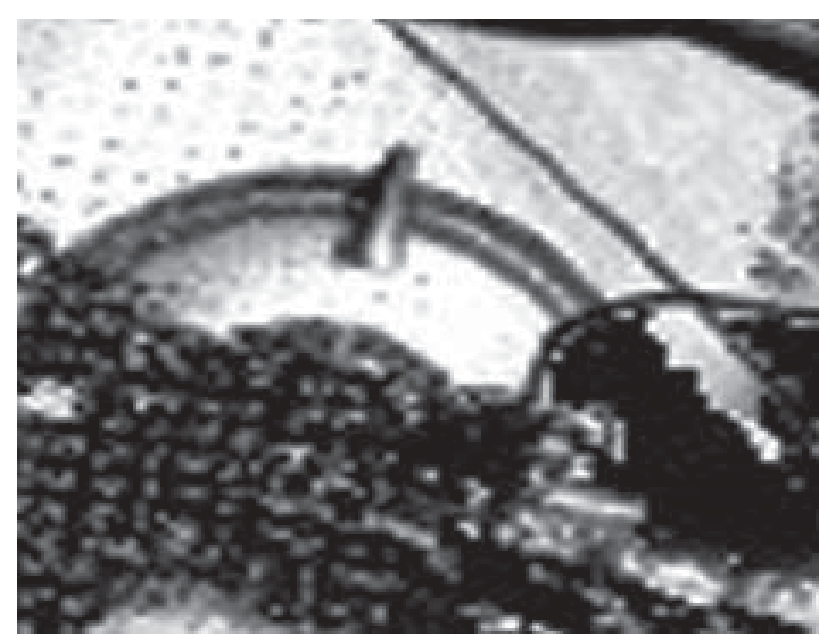


Emisión J unio 21, 2005

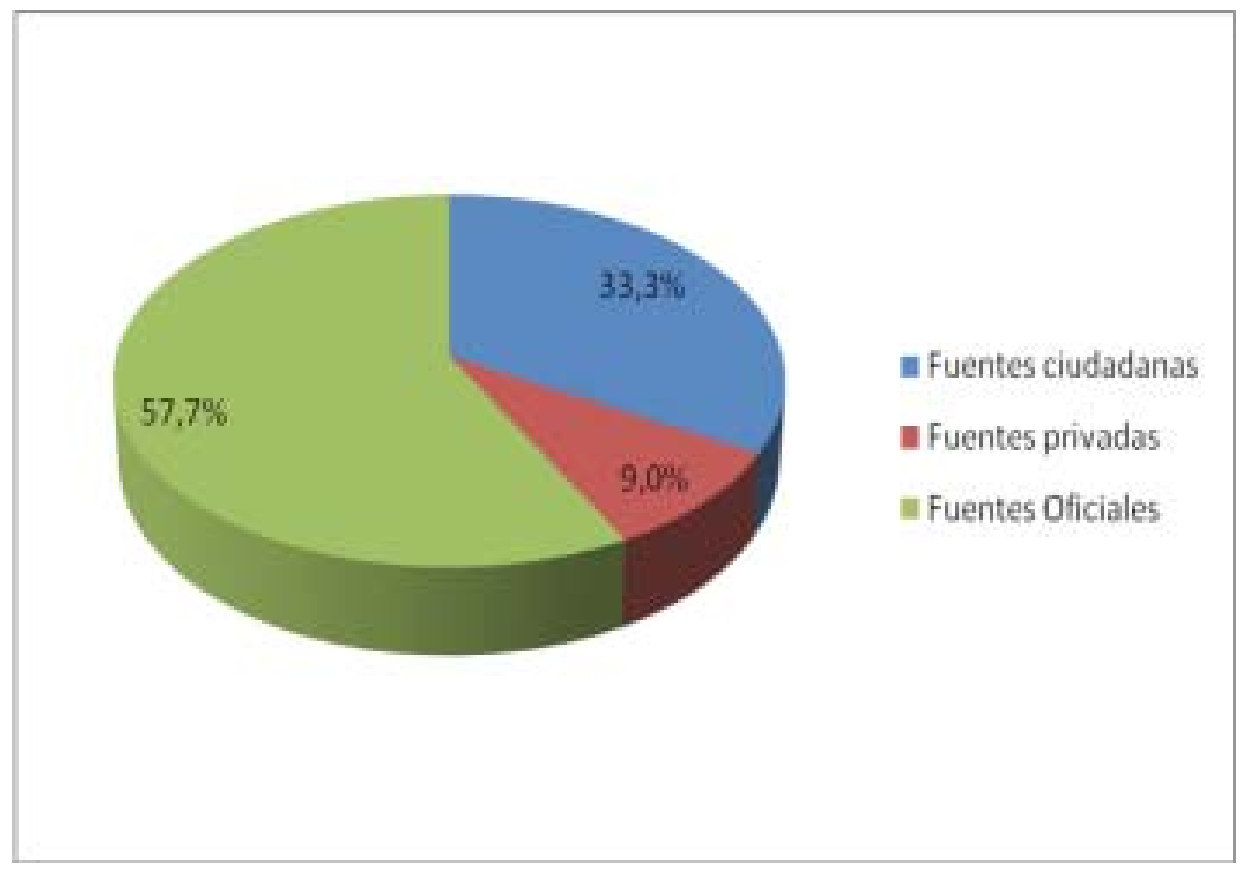

Emisión J unio 22

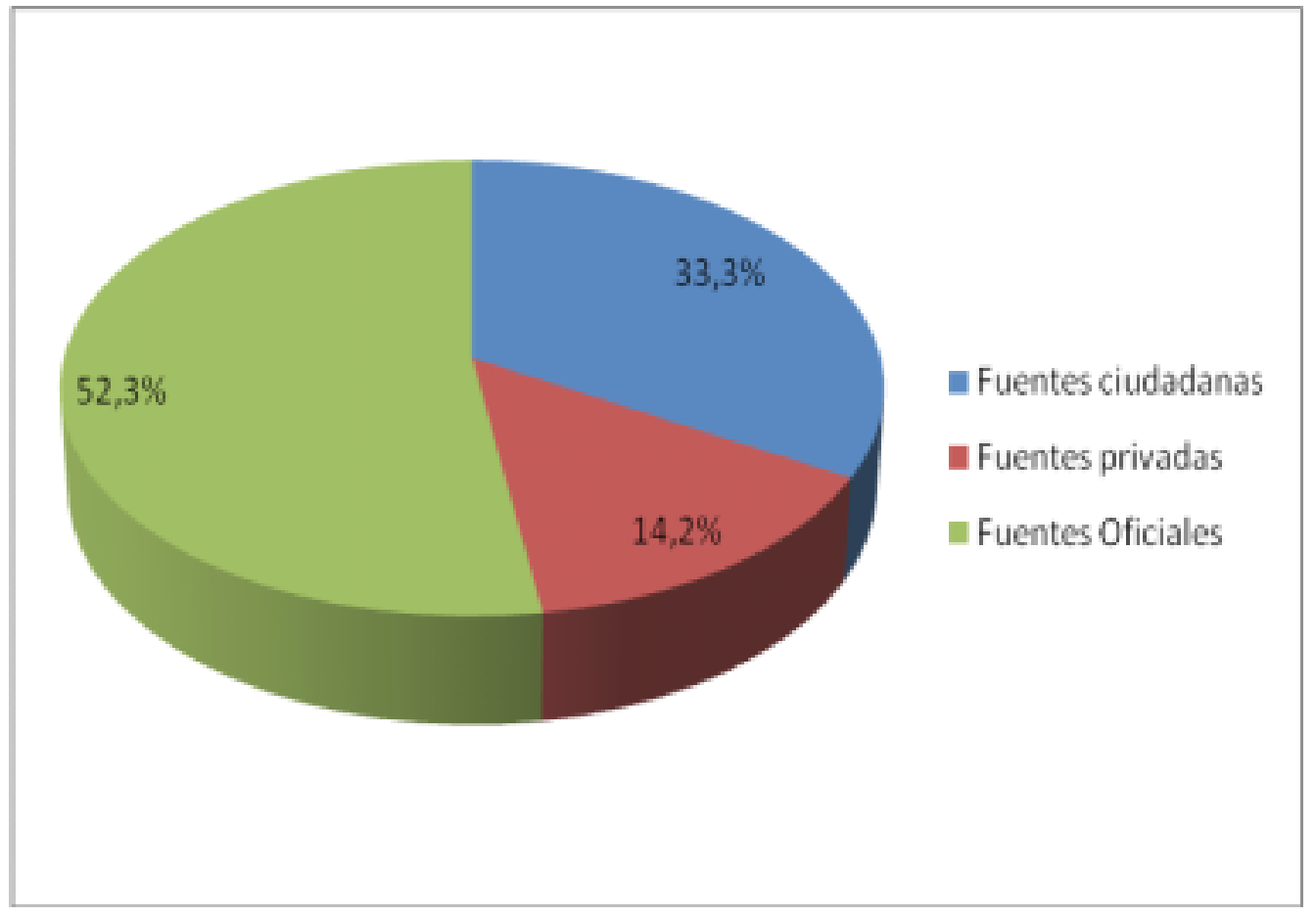




\section{Emisión J unio 23}

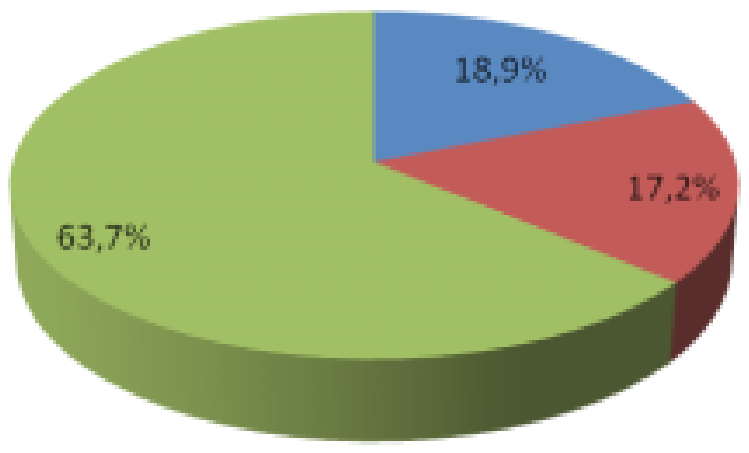

- Fuentes ciudadanas

- Fuentes privadas

m Fuentes Oficiales

\section{Emisión J unio 24}

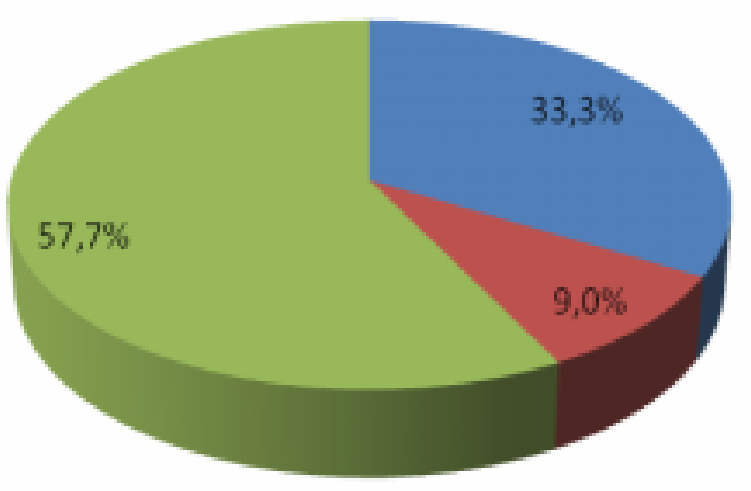

- Fuentes ciudadanas

Fuentes privadas

Eventes Oficiales

De modo que buena parte del énfasis en las audiencias se da, más que en la cantidad de tiempo que se les dedica, en el estilo en que se incluye: Ilamadas de los oyentes - en su mayoría víctimas o ciudadanos organizados- , seguimiento a quejas, y los desplazamientos de Álvaro Miguel Mina, todo ello inscrito en lo que hemos denominado en las tablas como Fuentes Ciudadanas. 


\section{Diario Occidente y Noticiero del Pacífico}

«Queremos ser modernos, controvertidos, efectivos, populares. Para eso nuestros informes serán cortos, precisos y concisos. Su forma será tan importante como el contenido. Incluirán diversas fuentes, la voz de los ciudadanos será protagónica».

(Aviso institucional ubicado en el cubículo de los reporteros del Diario Occidente

«Periodismo Ciudadano» era el evento académico realizado en la Universidad J averiana en el 2006, organizado conjuntamente por su Facultad de Comunicación Social y el Diario Occidente. En dicho acto, participó como conferencista el en ese momento editor del diario, el egresado de la Universidad del Valle Harold J iménez. Segundos antes de subir a la tarima empezó a sonar una música muy por el estilo de la taquillera película «Pretty Woman». Entonces Harold subió las escaleras y empezó a desfilar por la tarima, mientras se quitaba el elegante saco que portaba y que segundos después terminó lanzando al piso. Igual suerte corrió la corbata, y antes de que la temperatura del auditorio subiera, dijo: «El periodismo ciudadano le quita el frac al periodismo». Así dio inicio a su charla.

¿De que vivimos? se explica de una manera muy sencilla, vivimos de la publicidad. Así como lo hace la radio y la televisión, los anuncios son los que sostienen y pagan todo el proceso de producción del periódico. Esto nos permite varias cosas: por un lado nosotros garantizamos a nuestros clientes cero devolución, si le decimos al cliente que imprimimos treinta mil periódicos saben que treinta mil periódicos se van a lee (...) Por otro lado, desde el punto de vista comercial, nos permite dirigir nuestra circulación; si nosotros creemos que hoy debemos llegar a la gente de estrato dos, pues los mandamos para allá; si creemos que debemos llegar a sectores aledaños a los centros comerciales o a unidades residenciales pues nosotros - como somos los dueños del periódico en términos generales y podemos distribuirlo donde queramos o donde nuestros clientes quieran- entonces nosotros hacemos eso. (Harold Jiménez)

El periódico Occidente - fundado en 1961 con una orientación política conservadora- tuvo una seria crisis económica, antes de ser comprado por unos empresarios europeos - la familia portuguesa Oliveira- y convertirse, desde el año 2002, en el Nuevo Diario Occidente. Desde entonces cambió radicalmente en algunos aspectos: pasó a ser tamaño tabloide y, siguiendo la tendencia europea traída por sus nuevos dueños, pasó a ser de distribución gratuita, sosteniéndose aparentemente a través de la pauta publicitaria. De su sede tradicional en la Calle 12, en el centro de Cali, pasaron al Centro Comercial Chipichape, donde sus dueños son accionistas. Se introdujo más tecnología y las condiciones laborales de sus empleados se ajustaron a las garantías de ley.

También el Noticiero del Pacífico, por la misma época de Occidente, fue comprado por la familia portuguesa, y desde entonces se creó una alianza entre los dos medios, alianza que les permite compartir la sede, los conductores, las secretarias, y por supuesto algunos - no todos- de los periodistas. De hecho, la comunicadora social egresada de la Universidad del Valle, Rosa María Agudelo, cumplía en esa época el doble rol de directora del Noticiero del Pacífico y de gerente de ambos medios. Mientras su trabajo se centraba más en el Noticiero del Pacífico, el de su compañero, también egresado de la Universidad del Valle, Harold J iménez, era el de editor del diario. 
Al lado de Harold hay un equipo compuesto por cerca de 15 periodistas, la mayoría de ellos graduados de diversas universidades de la ciudad. De la mano de Harold J iménez, trabajaba el periodista Mauricio Ríos, recién egresado de la Universidad Santiago de Cali, quien hacía las veces de coordinador de redacción, una especie de jefatura de dirección, rol que por lo general ha estado en los distintos medios a cargo de personas de larga trayectoria y no, como en este caso, en el primer trabajo en medios.

«Yo coordino toda la planta de periodistas y reporteros gráficos, tengo mucha relación con la gente de Occidente On Line, coordino también la parte del transporte. A mi mando está Harold Jiménez, pues él tiene otras ocupaciones que no son tan tácticas como las mías. A mi me toca encargarme mucho del trabajo práctico, del día a día, del corre- corre, de ver qué noticias se van a cubrir, de garantizar que la persona que la va a cubrir tenga transporte, si necesita reportero gráfico que el reportero gráfico lo acompañe, de ver la pauta, de ver qué paginas van a ir en la edición del día siguiente, a qué secciones se le dan más páginas que a otras (...) También algunos días de la semana tengo a cargo el editorial del diario, algunas veces lo hace Harold, otras veces lo hace Rosa María, pues ahí nos repartimos el trabajo. Tengo a mi cargo hacer la primera página del diario que es la portada, revisar títulos, revisar textos, sentarme con el periodista después de que llega de hacer su reportería a ver qué enfoque le vamos a dar a la información».

Además de lo anterior, tiene una columna diaria de chismes políticos denominada Graffiti, y presentaba diariamente en el Noticiero del Pacífico las noticias que serían titular al día siguiente en Occidente. En síntesis, una rutina de trabajo en la que se reitera lo dicho anteriormente: trabajo de oficina, múltiples funciones (administrativas y editoriales), y total claridad sobre lo que debe hacerse. Sin embargo, en el caso del Diario Occidente la interiorización de las relaciones entre el componente editorial y el económico por parte de los periodistas es mucho más funcional: vemos que se reitera lo dicho por la periodista de RCN, en el sentido de que es la parte comercial la que determina los sectores sobre los cuales se debe hablar en la sección del Correcaminos; pero en este caso, debido a las lógicas entre la prensa gratuita, la publicidad y la distribución del periódico, los periodistas deben integrar de un modo más estratégico y más consciente ambos componentes: «uno no puede hablar mal del que está pautando en el periódico», dice la periodista de este medio Claudia Alexandra Delgado. La lógica que hace muchos años ingresó a la radio en la que el periodista se pone su propio sueldo y, en ese sentido, hace las veces también de vendedor, ingresa en este medio de una manera más sofisticada si se quiere, pero a la vez exigiendo mayor lealtad y subordinación al medio: no es para ponerse directamente el propio sueldo, sino para garantizar la sostenibilidad de la empresa (y en consecuencia, el lugar del periodista en ella).

Del Noticiero del Pacífico, que salió del aire después de 16 años, puede decirse algo similar. Su directora y gerente, Rosa María Agudelo, se encarga en consecuencia de dirigir las políticas editoriales del medio y de conseguir clientes. Su rutina diaria se divide entre lo uno y lo otro.

«Los miércoles es la reunión de la parte financiera, todas las mañanas nos concentramos en las ventas; es un día que analizamos cómo vamos hasta el momento, si se han cumplido las metas del mes, si vamos bien con el presupuesto. Al mediodía es la planeación editorial del noticiero (...) El jueves es administrativo también, se revisa el flujo de caja, el estado financiero comparativo, se forman cheques, se hacen contratos si es necesario. Y desde ese día empiezo a cuadrar citas: si voy a visitar a un cliente o si quiero hablar con el alcalde de Yumbo, etc.»

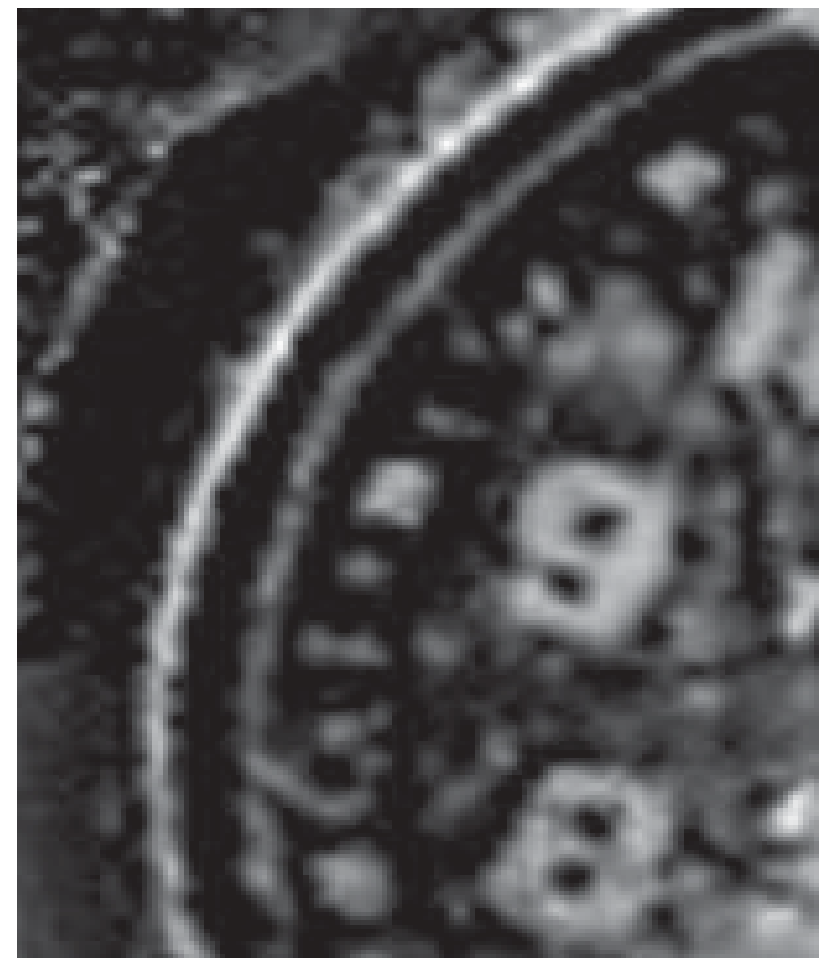


En términos más generales, esta responsabilidad en lo relativo a la sostenibilidad económica del medio ha conducido a que el término «cliente» empiece a ser parte de manera más natural en la jerga de los periodistas; así mismo, fenómeno como el de «free press» en el que las empresas pretenden pasar publicidad como información a través de canjes (o sin pagar por ello), incide en que los redactores deban sopesar lo que se publica no sólo desde los criterios de noticiabilidad de orden más periodístico, sino también empresarial, en ese sentido, aparecen con bastante frecuencia en el periódico actividades sociales, artículos sobre industria, investigaciones de tipo administrativo, promociones turísticas, símbolos de la vallecaucanidad (productos artesanales, comestibles, folclor).

Los dos criterios de noticiabilidad del diario son: a) Cercanía física: entre más cerca esté la información de Cali, más importancia tendrá, y se deja de lado su articulación con lo nacional; de igual o mayor manera ocurre a nivel regional, Io ocurrido en el Valle del Cauca se maneja parcialmente ya que lo producido son perspectivas oficiales que promueven «una imagen positiva y buena». B) Actualidad: Esta muy ligado a lo que se emite en otros medios (radio, televisión, internet); se hace mucho énfasis en las noticias positivas, aspecto que queda plasmado en la propuesta editorial del diario: "somos un medio de comunicación que le busca el lado bueno a la información y a los hechos... que siembra optimismo, alegría y positivismo... el diario Occidente no la va con los pesimistas ni quejumbrosos». En el ámbito nacional, se registran los acontecimientos políticos de violencia, las personalidades sociales y los ídolos mediáticos; la información en este caso también es extraída por medio de agencias, cuyas fuentes corresponden en gran parte de las ocasiones a voces oficiales.

En el plano internacional, las imágenes son repetitivas: dirigentes políticos de países desarrollados, de naciones convulsionadas por guerras, conflictos y litigios; fotos de regiones y ciudades azotadas por catástrofes, adelantos científicos, proyectos tecnológicos, personalidades de las artes, las ciencias, los deportes (fútbol, automovilismo, en ocasiones ciclismo) y el espectáculo.

En el caso del Noticiero del Pacífico, los criterios generales de noticiabilidad también están dados por el carácter regional y local. El noticiero

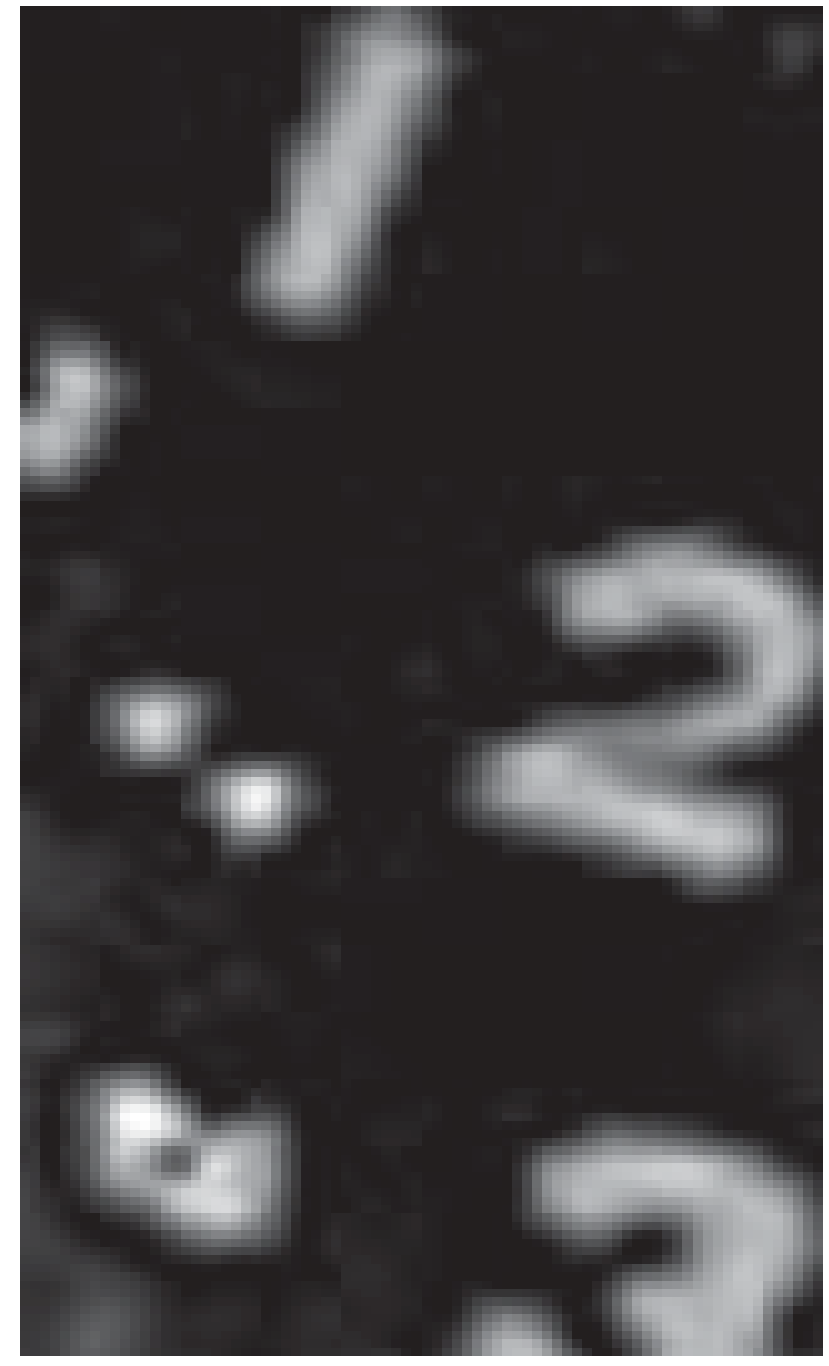

estaba en tres bloques: a) Noticias generales: de tipo judicial, gubernamental y campañas sociales, entre otras; aquí se incluyen secciones como «La toma de la comunas» (ver más adelante), «Al tablero» (la opinión de un especialista sobre un problema del momento) y «El Televoto» (participación telefónica o virtual de los televidentes acerca de un asunto coyuntural). b)

Noticias deportivas: en ellas el noticiero atraviesa la barrera entre lo regional y lo nacional y lo hace de la mano del fútbol; es de destacar que, las imágenes que sirven de piso, provienen de canales privados como Caracol, RCN, Fox Sports y SKY; ahora bien, el noticiero se interesa por cubrir los campeonatos con sede en Cali, ésta es la única oportunidad que tiene la sección para alimentarse de testimonios. C) Notas de

farándula: en realidad, mezcla notas culturales, de farándula (moda), de cine («E cartelera»), de rumba («El mundo según Pily»), deportivas («Eliteaventura»), y otras secciones como «Élite sin límites» $\mathrm{y}$ «El Boom de la semana». 
En los siguientes cuadros podrá verse la importancia que tienen las fuentes oficiales en el Diario Occidente:

\section{Fuentes Citadas por el Diario Occidente Junio 20 de 2005}

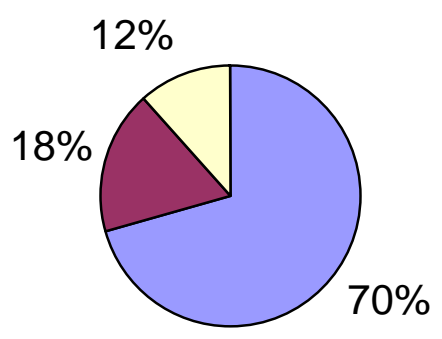

$\square$ No. Apariciones fuentes oficiales

$\square$ No. Apariciones fuentes privadas

$\square$ No. Apariciones fuentes ciudadanas 


\section{Fuentes Citadas por el Diario Occidente Junio 25 de 2005}

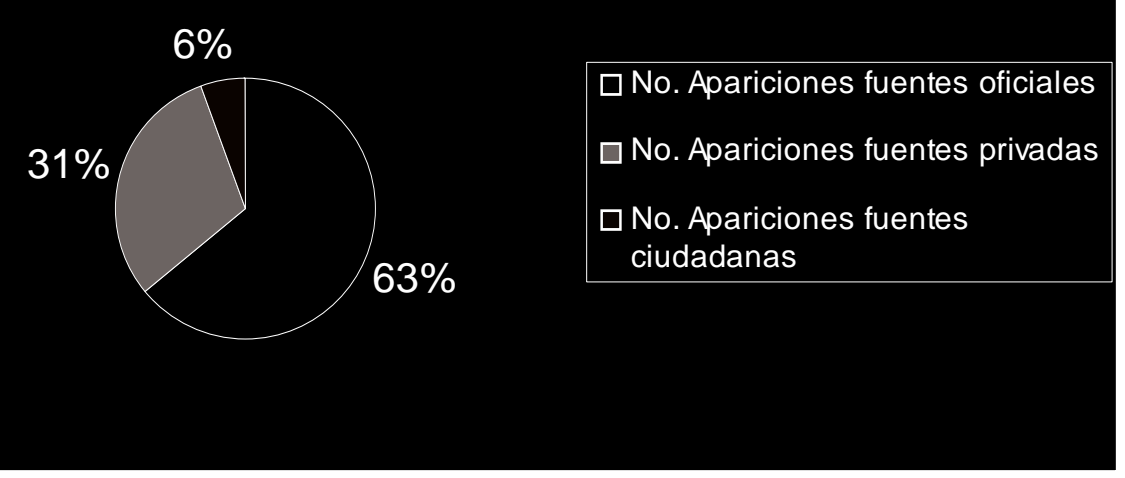


Si se tiene en cuenta lo expuesto anteriormente sobre las características de la prensa gratuita y sobre la injerencia de la parte comercial en la editorial, puede explicarse el significativo peso que tienen en este medio las fuentes privadas (mucho mayor que en el caso del noticiero radial Cómo Amaneció Cali).

\section{Conclusión}

En síntesis, en los distintos medios abordados, es evidente que las fuentes de información oficiales siguen siendo dominantes. En una muy buena parte de ello, las lógicas de producción detalladas anteriormente explican la imposibilidad de que sea de otra manera. Los boletines y las llamadas (de doble vía) de los funcionarios interesados, siguen siendo los insumos por excelencia.

Ahora bien, cuando nuevas agendas sociales logran ingresar a las agendas informativas, la tendencia de los medios es adaptar lo nuevo a los tratamientos textuales pre- establecidos. De ese modo, se reproducen estereotipos sociales sobre el tema en cuestión o se contribuye a la generación de otros nuevos. Esto se explica fundamentalmente porque ante la dificultad de flexibilizar las rutinas de trabajo en los medios, los nuevos actores y temas deben aj ustarse a las condiciones de producción ya pre- existentes, por una parte; por otra, deben ajustarse a las lógicas comerciales propias del medio. Por ello se hace necesaria una intervención permanente de los agentes externos que promueven esas agendas sociales (universidades, organizaciones no gubernamentales, movimientos sociales y otras organizaciones) para sensibilizar y capacitar a los periodistas en un tratamiento más preciso y ajustado a los propósitos que promueven.

\section{Notas}

${ }^{1}$ Definidas como aquellas compuestas por actores sociales que no hacen parte de las fuentes oficiales ni de las fuentes privadas, y cuyos criterios de aparición en los medios se circunscriben especialmente a sus roles como víctimas, reivindicadores y testigos, de acuerdo a la clasificación realizada por Patrick Charaudeau (2003). Otras caracterizaciones de las fuentes ciudadanas son abordadas en un capítulo precedente de la investigación. 
${ }^{2}$ A propósito de esto, vale la pena recordar un aparte del documental de Oscar Campo, «Noticias de guerra», en el que el director de 90 Minutos en esa época, J osé Vicente Arizmendi, dice, refiriéndose al trabajo del reportero Miguel Angel Palta, que no es necesario que él, como director, revise la edición de sus notas, porque ambos ya saben qué es lo que ésta debe contener.

${ }^{3}$ Este programa estuvo dedicado a debatir sobre la muerte de dos camarógrafos de los noticieron Caracol y RCN, mientras perseguían la buseta en la que guerrilleros de las FAR habían secuestrado a los diputados a la Asamblea del Valle del Cauca.

${ }^{4}$ Elliot, Phillip. Citado por Abril, Gonzalo. Ibidem, p.307.

${ }^{5}$ Al respecto dice Sergio Ramírez: «las representaciones sociales de la conciencia profesional se desdoblan así en una primera dimensión, a la vez conciente e implícita - la de las teorías y modelos dominantes que organizan cuerpos de conocimientos manipulados por el grupo profesional- y en una dimensión de nociones originadas en dichas teorías e incorporadas a los aspectos habituales, cotidianos y societarios del ejercicio profesional, aquellos que van más allá del ámbito cerrado de una comunidad de expertos». En: Comunicación e ideologías profesionales. Control del conocimiento y conocimiento del control - Revista Taller de Comunicación 3, Departamento de Ciencias de la Comunicación, Universidad del Valle, 1989, p.4.

${ }^{6}$ En: Bajo todos los fuegos. Los periodistas en el conflicto armado. Proyecto Antonio Nariño. Bogotá, 2002.

${ }^{7}$ Abundan los ejemplos de egresados que durante su carrera universitaria demostraron inteligencia y ánimo crítico, y una vez empiezan a trabajar en un medio de información masivo se adhieren rápidamente a sus ideologías profesionales y a sus lógicas de producción.

${ }^{8}$ Leo Quintero, director del noticiero.

${ }^{9}$ Ibíd.

\section{Bibliografía}

Abril. Gonzalo. Teoría general de la información. Cátedra, Madrid, 1997.

Accardo, Alain. En torno a la subjetividad de los periodistas. Una libertad políticamente correcta (hacer lo que se debe hacer). En: le Monde Diplomatique, julio 2000

Ầ. Con un periodista. En: La Miseria del Mundo. Pierre Bourdieu, et.

Bourdieu, Pierre. Sobre la televisión. Anagrama, Barcelona, 1997

Charaudeau, Patrick. El discurso de la información. La construcción del espejo social, Gedisa, Barcelona, 2003.

Kapuscinski, Ryszard. Encuentro con el otro. Crónicas Anagrama. España, 2007 Los cínicos no sirven para este oficio. Sobre el buen periodismo.

Anagrama, Barcelona, 2002

Ramírez, Sergio. Comunicación e ideologías profesionales. Control del conocimiento y conocimiento del control. En: Taller de Comunicación 3, Departamento de Ciencias de la Comunicación, Universidad del Valle, Cali, 1989. Van Dijk, T.A. La noticia como discurso. Comprensión, estructura y producción de la información. Paidós comunicación, Barcelona, 1996. 